\title{
Implementası Medıa Bulletın Board dalam Menıngkatkan Kemampuan Membaca Permulaan dı Tk PAUD Anak Bangsa Kota Palembang Provınsı Sumatera Selatan
}

\author{
Indah Dwi Sartika ${ }^{*}$ \\ ${ }^{1}$ UIN Raden Fatah Palembang
}

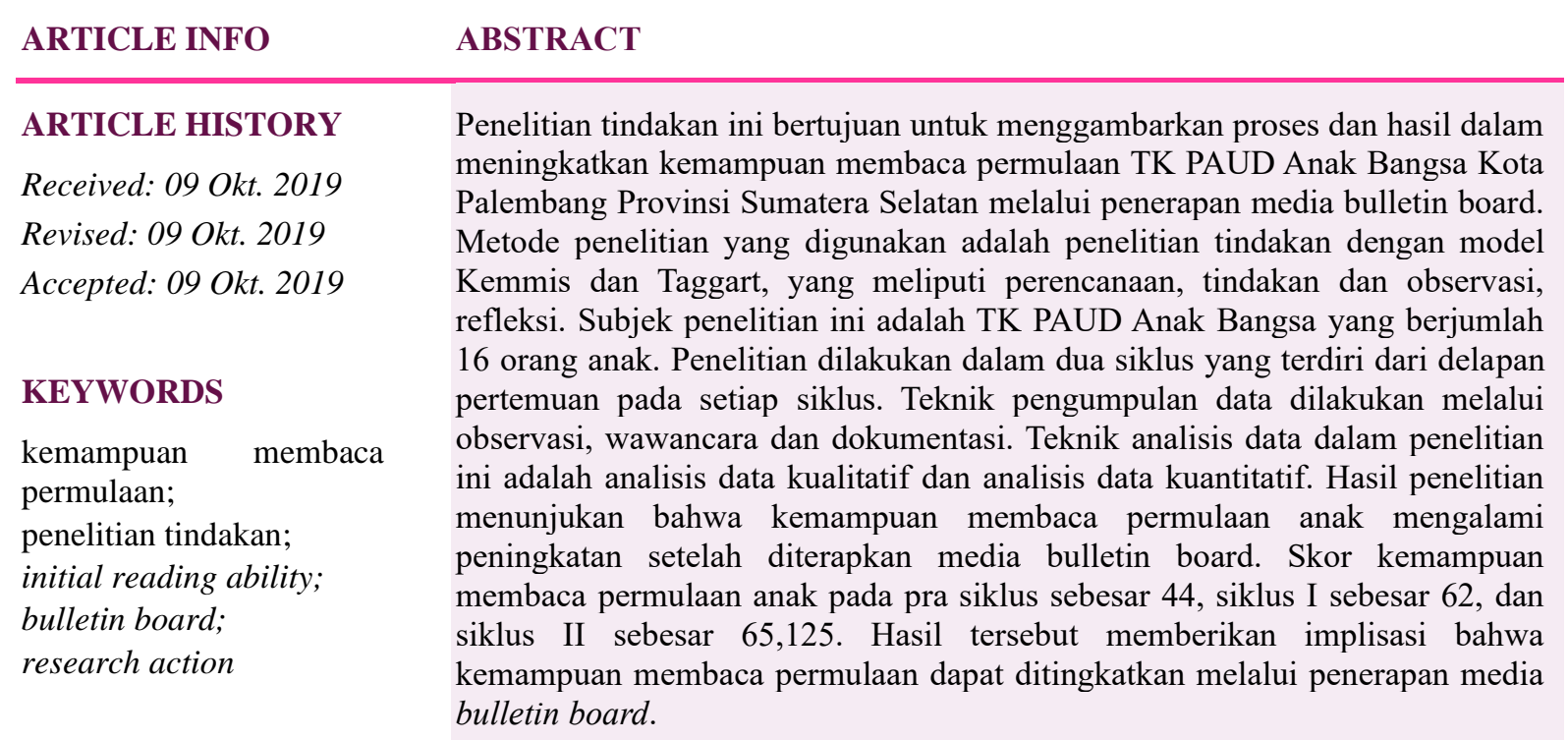

Research action aims to describe the process and results in improving the ability to read the beginning of TK PAUD Anak Bangsa of Palembang City South Sumatera Province through the application of Media bulletin board. The research methods used are research actions with the Kemmis and Taggart models, which include planning, action and observation, reflection. The subject of this research is TK PAUD Anak Bangsa, a total of 16 children. Research is conducted in two cycles consisting of eight meetings on each cycle. Data collection techniques are conducted through observation, interviews and documentation. The data analysis techniques in this study are qualitative data analysis and quantitative data analysis. The results showed that the ability to read children's beginnings improved after the media bulletin board was applied. Scores of children's start reading on the pre-cycle of 44, cycle I by 62, and cycle II by 65.125. The results gave implisation that the ability to read the start can be increased through the application of Media bulletin board.

CONTACT: Indah Dwi Sartika $\bigotimes$ indahdwi@gmail.com ㅍN Raden Fatah Palembang 


\section{PENDAHULUAN}

Membaca pada dasarnya harus dikenalkan pada anak sejak usia dini, sebagaimana di sampaikan oleh Sue Hamilton Smith \& Dan georgeson (2015 : 36) dalam penelitiannya yang menyebutkan bahwa sebuah komunitas professional language to literacy berfokus pada pengembangan kemampuan bahasa lisan dan keterampilan membaca pada anak 0-5 tahun. Pada anak usia dini membaca mulai dikembangkan dengan mengenalkan anak akan simbolsimbol tulisan serta makna dari tulisan, oleh sebab itu kemampuan membaca pada anak usia dini disebut dengan kemampuan membacapermulaan.

Keterampilan membaca dapat dikembangkan pada anak usia 0-5 tahun, faktor lingkungan lebih berperan dalam mengembangkan kemampuan membaca, pendekatan pembelajaran mempengaruhi kemampuan membaca permulaan, strategi membaca mempengaruhi kemamuan membaca permulaan. Oleh sebab itu, peneliti ingin melakukan penelitian menggunakan media bulletin board dalam peningkatkan kemampuan membaca permulaan anak. Dimana penelitian ini dilakukan di TK PAUD Anak Bangsa Kota Palembang Provinsi Sumatera Selatan. Penelitian ini dianggap penting dilakukan melihat belum adanya penelitian terdahulu yang menggunakan media bulletin board dalam peningkatan kemampuan membaca permulaan. Selain itu, untuk mengubah strategi pembelajaran di sekolah, dengan memanfaatkan media bulletin board. Sehingga anak belajar sambil bermain dengan keadaan senang dan tanpa paksaan. Dimana pada hasil observasi awal telah terlihat bagaimana kegiatan pembelajaran di sekolah yang menekankan pada kegiatan baca, tulis, dan berhitung.

Brittany R. Cooper (2014: 1249) mengemukakan bahwa kemampuan awal membaca diantaranya bahasa lisan, mendengarkan pemahaman, kesadaran fonologi, keterampilan cetak, dan pengetahuan abjad yangdijadikan dasar untuk belajar membaca dan keberhasilan akademik dimasa yang akan datang.

Seefeldt dan Barbara (2008: 323) mengungkapkan bahwa kesadaran fonemik (bunyi), perkembangan pengetahuan tentang huruf, dan pemahaman huruf cetak adalah tiga kemampuan penting yang perlu dicapai anak-anak agar mereka siap menerima manfaat dari instruksi membaca yang formal. Hal tersebut jelas bahwa kemampuan membaca awal pada dasarnya yang harus dikuasai oleh anak yaitu kemampuan akan pemahaman bunyi, pengenalan huruf dan pemahaman huruf cetak. Hal tersebut erat hubungannya dengan kegiatan keseharian yang dilakukan anak, yang erat dengan dunia baca.

Hacer Ulu dan Hayati Akyol (2016: 223) mengungkapkan bahwa proses yang biasanya berlangsung pada kelas-kelas awal yaitu proses recording dan decoding, yang dikenal dengan membaca permulaan. Proses ini dimana mengartikan bawa proses dimulai dari munculnya katakata dan kalimat yang kemudian diasosiasikan dengan bunyi-bunyian yang sesuai dengan sistem tulisan yang digunakan, serta proses penerjemahan rangkaian grafis ke dalam kata-kata. Proses dalam membaca permulaan lebih menekankan pada pengenalan korespondensi rangkaian huruf dengan bunyi-bunyi bahasa.

Robert e. Ownest, JR (2012: 369) menyatakan bahwa beberapa anak-anak belajar untuk mengenali kata dengan bentuk kata, sementara yang lain mulai "membaca" berdasarkan huruf pertama dan terakhir dari sebuah kata. Meskipun banyak anak TK tahu nama huruf, pemahaman mereka tidak lengkap untuk suara vokal dan banyak suara konsonan. Dalam mencoba untuk membaca, mereka menggunakan kombinasi hafal bentuk kata, nama huruf, dan menebaknebak. Hal tersebut terlihat bahwa pemahaman anak dalam membaca masih mengalami kesulitan dalam memahami bentuk huruf dan bunyi. Tahapan perkembangan prereading misalkan pemahaman cetak, pengenalan huruf, awal dan akhir suara, menciptakan kata-kata berima, pengenalan kata. Jelas terlihat bahwa pada tahap perkembangan kemampuan membaca permulaan pada anak, pada dasarnya hanya menekankan anak untuk mengenal kata demi kata. 
Berdasarkan beberapa teori yang telah dikemukakan, maka dapat disintesiskan bahwa kemampuan membaca permulaan merupakan kesanggupan anak untuk 1) memahami bunyibunyi, 3) memahami bentuk huruf dan bunyinya, serta 3) memahami makna dari kata yang dibaca.

Untuk meningkatkan kemampuan membaca permulaan pada anak, peneliti menggunakan media bulletin board sebagai model dalam penelitian. Bulletin board merupakan salah satu media visual yang digunakan dalam pembelajaran. Bulletin board sangat efektif digunakan di bidang pendidikan karena dapat menyesuaikan dengan kondisi lingkungan dimana permasalahan terjadi.

Stein (2009: 440) mengungkapkan bahwa bulletin board digunakan untuk memberikan informasi, meningkatkan kesadaran, merangsang minat, dan memotivasi individu untuk bertindak. Mereka juga dapat digunakan untuk menginspirasi. Misalnya, kutipan yang berlaku,salam liburan, dan ekspresi terima kasih dapat diposting.

Michael Gravois (2003: 4) yang dapat dipahami bahwa anak belajar banyak tentang membaca dari label, tanda-tanda, dan jenis lain dari cetak yang mereka lihat di sekitar mereka. Label cetak sangat terlihat pada objek, tandatanda, dan bulletin board di ruang kelas menunjukkan penggunaan praktis dari bahasa tertulis.

Dari beberapa penjelasan mengenai media bulletin board, peneliti berniat menggunakan media bulletin board dengan harapan kemampuan membaca permulaan anak dapat ditingkatkan. Bulletin board didesain sesuai dengan kebutuhan anak, mengandung gambar dan kata yang dapat mendorong minat baca anak, dan pemahaman anak akan kata yang dijumpainya.

\section{METODE}

Penelitian ini menggunakan metode penelitian tindakan (action research). Desain penelitian tindakan yang digunakan adalah model Kemmis dan Mc Taggart yang menggunakan empat komponen meliputi, perencanaan, tindakan dan observasi, refleksi. Instrumen pengumpulan data yang digunakan dalam penelitian ini adalah non tes, yaitu: 1) Lembar observasi, 2) Catatan wawancara, 3) Catatan lapangan, dan 4) Dokumentasi, dengan menggunakan teknik pengumpulan data berupa observasi dan wawancara.

Teknik analisis data yang dilakukan dalam penelitian ini yaitu teknik analisis data kualitatif dan teknik analisis data kuantitatif. Teknik tersebut menggunakan pendapat Mills dan Huberment yang terdiri dari: data collection, data reduction, data display dan data conclusing drawing/verification.

\section{HASIL DAN PEMBAHASAN}

Hasil penelitian menunjukkan bahwa kemampuan membaca permulaan TK PAUD Anak Bangsa Kota Palembang Provinsi Sumatera Selatan sudah mulai meningkat dari pra- intervensi sampai siklus II. Berikut perbandingan data hasil kemampuan membaca permulaan anak pada pra-Intervensi, siklus I dan siklus II. Berikut data hasil kemampuan membaca permulaan anak kelompok B TK Sehati.

Hasil analisis yang telah dilakukan menunjukkan bahwa adanya peningkatan rata - rata tingkat capaian perkembangan kemampuan membaca permulaan anak TK Sehati Kalideres yaitu sebesar 52 yang berada pada kategori berkembang sesuai harapan, dengan nilai tingkat capaian perkembangan rata-rata pra-intervensi sebesar 44. Dalam pelaksanaan siklus I terlihat peningkatan skor rata-rata tingkat capaian perkembangan kemampuan membaca anak secara menyeluruh sebesar 8. Pada siklus II nilai rata-rata tingkat capaian perkembangan anak pada kemampuan membaca secara keseluruhan yaitu sebesar 65,125 yang berada pada kategori berkembang sangat baik. Adapun besarnya peningkatan pada siklus II sebesar 10,125. 
Berdasarkan kesepakatan antara peneliti dengan kolabolator bahwa penelitian dikatakan berhasil jika $71 \%$ dari jumlah anak atau 12 dari 16 orang anak mencapai $75 \%$ dari TCP maksimal, atau sebesar 57. Dari hasil pengamatan yang dilakukan pada siklus I, TCP anak secara keseluruhan belum mencapai TCP minimal, sehingga penelitian dilanjutkan pada siklusselanjutnya. Pada siklus II nilai rata-rata tingkat capaian perkembangan anak yaitu sebesar 62,125 yang berada pada kategori berkembang sangat baik. Terdapat 13 orang anak yang mencapai TCP minimal yaitu 57, dengan begitu penelitian ini dikatakan telah berhasil.

Pada indikator menyebutkan bunyi penggabungan huruf vokal dan konsonan, pada siklus I sebesar 7,06 yang berada pada kategori mulai berkembang. Adapun selesih skor rata-rata tingkat capaian perkembangan pada indikator ini di Siklus I dengan Pra-intervensi sebesar 1,81. Rata-rata skor tingkat capaian perkembangan anak pada indikator ini sebesar 9,06 dengan kategori berkembang sesuai harapan. Adapun peningkatan skor rata-rata tingkat capaian perkembangan anak sebesar 2 .

Dari hasil pengamatan pra-intervensi, terdapat beberapa indikator yang bermasalah, yaitu 1) menyebutkan penggabungan huruf vokal dan konsonan; 2) membaca kata; dan 3) menyebutkan makna kata yang dibaca. Masing-masing indikator mengalami peningkatan di setiap siklusnya. Indikator membaca kata memiliki skor rata- rata tingkat capaian perkembangan anak pada indikator membaca kata pada siklus I yaitu sebesar 6,56, sebelumnya pada pra-intervensi skor rata-rata tingkat capaian perkembangan anak sebesar 5. Besarnya peningkatan antara praintervensi dan siklus I sebesar 1,56. Adapun rata-rata tingkat capaian perkembangan kemampuan membaca anak pada indikator membaca kata pada siklus II, secara keseluruhan yaitu 9,06. Peningkatan ratarata tingkat capaian perkembangan anak yaitu sebesar 2,5.

Indikator menyebutkan makna kata yang dibaca rata-rata skor tingkat capaian perkembangan anak siklus I pada indikator tersebut secara menyeluruh yaitu sebesar 6,43 dengan kategori mulai berkembang, dan skor tingkat capaian perkembangan anak pada pra-intervensi sebesar 4,94 dengan kategori belum berkembang. Adapun besarnya peningkatan tingkat capaian perkembangan anak yaitu sebesar 1,49. Rata-rata nilai keseluruhan kemampuan membaca pada indikator menyebutkan makna kata yang dibaca pada siklus II sebesar 8,81 yang berada pada kategori mulai berkembang. Adapun selesih skor rata-rata tingkat capaian perkembangan pada indikator ini di Siklus II dengan siklus I sebesar 2,38. Berdasarkan hasil analisis pada siklus I dan II, terlihat bahwa kemampuan membaca permulaan anak telah mangalami peningkatan. Karena pada dasarnya anak usia dini atau tepatnya anak taman kanak-kanak merupakan masa dimana anak harus dapat belajar membaca dengan penuh makna. Adapun data kemampuan membaca permulaan anak, dapat digambarkan pada grafik di bawah ini:

Dalam penelitian ini terdapat peningkatan kemampuan membaca permulaan anak di berbagai aspek, diantaranya aspek mengenal bentuk huruf. Dalam pengenalan huruf, pada penelitian ini memanfaatkan berbagai kartu huruf dan kartu gambar. Anak mengenal kata melalui gambargambar yang dijumpainya, mengetahui berbagai huruf yang ada pada setiap kata. Hal tersebut dilakukan sebagaimana bahwa konsep anak belajar melalui benda konkrit.

Piaget dalam Papalia (2014: 244) menyebutkan bahwa perkembangan anak usia dini usia 2-7 tahun sebagai tahap praoprasional dalam perkembangan kognitif, karena anak-anak pada usia tersebut belum siap untuk terlibat dalam operasi mental logis. Dari pendapat tersebut, diketahui bahwa anak belajar melalui benda konkrit dan memanfaatkan alat indera nya. Dalam penelitian ini, seluruh alat indra anak dilibatkan kecara aktif, seperti anak harus dapat mendengarkan berbagai perintah yang diberikan guru mengenai bulletin board, melihat bagaimana huruf-huruf akan dirangkai menjadi kata, dan bahkan merasakan dengan dapat mempraktekkan beberapa informasi yang ia peroleh dari bulletin board seperti menggosok gigi. 
Memahami bunyi huruf, pada aspek ini anak belajar bagaimana bunyi setiap huruf yang telah dijumpai. Memahami bagaimana bunyi huruf yang telah digabungkan. Kegiatan ini dapat dilakukan dengan menyebutkan huruf awal pada kata, menyebutkan kata dengan awalan yang sama, dan menyebutkan berbagai huruf yang didenngarnya.

Brittant Rhoades Cooper (2014:1254) menyebutkan tahapan perkembangan prereading misalkan pemahaman cetak, pengenalan huruf, awal dan akhir suara, menciptakan kata-kata berirama, pengenalan kata. Jelas terlihat bahwa pada tahap perkembangan kemampuan membaca permulaan pada anak pada dasarnya bagaimana anak belajar huruf dan kata dengan menekankan bunyi-bunyi di setiap huruf dan kata. Dalam penerapan media bulletin board, danak dapat mengenal dan menyebutkan huruf dengan bantuan kartu huruf, kartu gambar, dan kartu kata. Beberapa kegiatan permainan dilakukan, seperti tebak huruf, menunjukkan huruf, menrangkai huruf menjadi kata dan menyebutkan huruf pada gambar.

Pada aspek membaca kata, diketahui bahwa anak mengalami peningkatan kemampuan. Pelaksanaan penerapan media bulletin board dalam meningkatkan kemampuan anak membaca kata dilaksanakan dengan menyebutkan berbagai huruf yang ditemui, hingga anak mengeja dan membaca kata secara utuh bahkan secara kalimat, untuk memperoleh makna bacaannya. Hal tersebut sesuai dengan pendapat Robert e.Ownest,JR2012 : 369)menyatakan bahwa beberapa anak-anak belajar untuk mengenali kata dengan bentuk kata, sementara yang lain mulai "membaca" berdasarkan huruf pertama dan terakhir dari sebuah kata. Meskipun banyak anak TK tahu nama huruf, pemahaman mereka tidak lengkap untuk suara vokal dan banyak suara konsonan. Dalam mencoba untuk membaca, mereka menggunakan kombinasi hafal bentuk kata, nama huruf, dan menebak-nebak. Keseuaian pendapat tersebut dengan kenyataan yang terjadi di lapangan, dimana terdapat beberapa anak yang merangkai kata dengan menyemakan huruf-hurf awal, menyamakan huruf secara keseluruhan, menghafal dan membacanya secara langsung. Dalam kegiatan menggunakan media bulletin board, guru memberikan anak kesempatan untuk bereksplorasi langsung dengan berbagai alat bantu dalam pengreasian bulletin board. Kegiatan dilakukan guru dengan memancing anak untuk merangkai huruf dan merangkai kata.

Media bulletin board dirasakan dapat membantu anak dalam meningkatkan kemampuan membaca permulaan. Dalam penerapannya media bulletin board memberikan kesempatan kepada anak untuk mengenal huruf dan kata secara utuh. Anak memperoleh pemahamannya dari berbagai kata yang ia jumpai yang disertai gambar, sehingga konsep anak belajar tidak secara abstrak. Anak dapat menebak terlebih dahulu kata pada gambar, sehingga dikemudian waktu anak memahami kata yang menerangkan suatu gambar. Kegiatan lain pada penerapan media bulletin board didukung dengan aktivitas anak bernyanyi dan bergerak bersama untuk membangun konsep anak lebih dahulu dalam mengenal mengenal materi pembelajaran. Beberapa kegiatan lain dilakukan dengan menyelipkan permainan tebak huruf, sebut huruf dan menunjukkan huruf.

Dalam kemampuan membaca permulaan anak, masih terdapat banyak faktor lain yang mempengaruhi, karena pada dasarnya kemampuan membaca terkait dengan disiplin ilmu lain. Dapat digambarkan pada bagan berikut:

Ditinjau dari segi neurosains, membaca merupakan kegiatan yang erat hubungannya dengan memori anak. Einat Nevo dan Irit Bar-Kochva (154) menyebutkan bahwa "working memory has been linked to the development of various academic skills, incLuding reading". Dapat dipahami bahwa kemampuan membaca berhubungan erat dengan kerja memori. Hal tersebut menunjukkan bagaimana membaca memang dipengaruhi oleh kemampuan kognitif lainnya, seperti pemahaman anak akan lambang dan bunyi-bunyi. Media bulletin board digunakan dalam pembelajaran dengan memanfaatkan berbagai benda sekitar anak untuk menjadi bahan pembelajaran. Dalam kegiatan, anak memanfaatkan media bulletin board dengan menyebutkan 
bunyi-bunyi yang ditemui anak. Anak dapat bermain bersama untuk menebak bunyi huruf dan merangkai huruf.

Radka Wildova \& Jana Kropackova (2015: 880) membaca terkait erat dengan tingkat perkembangan berbicara anak, tingkat kosa kata mereka, kemampuan berkomunikasi, mendengarkan, mengartikulasikan dengan benar, dll. Dengan begitu terlihat bagaimana kemampuan membaca berhubungan erat dengan komunikasi anak. Dalam penggunaan media bulletin board, anak belajar membaca dan menambah kosakata melalui komunikasi yang dilakukan anak dengan lingkungan sekitarnya. Anak menyebutkan beberapa kata yang ia temui dan dapat berdiskusi bersama untuk memahami makna kata yang dibacanya.

Komunikasi pada anak diperoleh dari lingkungan sekitarnya. Bagaimana anak berkomunikasi dengan orang tua, guru dan teman sebayanya. Hal ini menunjukkan bagaimana adanya hubungan kemampuan membaca anak dengan ilmu sosial. Dimana ilmu sosial atau sosiologi menurut Roucek dan Warren dalam Soekanto (2012: 18) diartikan sebagai ilmu yang mempelajari hubungan antara manusia dalam kelompok- kelompok. Dari pendapat tersebut dapat disimpulkan bagaimana ilmu sosial membahas bagaimana hubungan individu dengan individu lain dalam kelompok. Hal ini terjadi disemua kalangan usia, termasuk pada usia dini. Anak memperoleh pengalamannya dari bagaimana interaksi anak dilakukan dengan lingkungan. Dalam kegiatan yang telah dilakukan, penggunaan media bulletin board mendukung kegiatan anak untuk dilakukan secara berkelompok. Sehingga pembelajaran menciptakan suasana yang komunikatif dan interaktif. Anak secara bersama mengkreasikan bulletin board pada setiap kelompoknya. Anak bermain bersama dalam merangkai huruf dan kata. Serta mengkomunikasikan hasil bulletin board pada setiap kelompoknya.

Pembelajaran membaca dapat dilakukan melalui kegiatan yang berhubungan dengan seni. Seefeldt (2008: 265) mengungkapkan bahwa kesenian merupakan alat ampuh dalam mengembangkan pikiran, bahasa lisan dan tulisan, dan cara-cara anak- anak mengetahui dan memahami diri dan dunia mereka. Dari penjelasan tersebut, bahwa dalam pembelajaran membaca dapat dilakukan melalui kegiatan seni seperti menyanyi, mengenal huruf atau membaca melalui kegiatan mewarnai atau merangkai huruf dengan berbagai media. Hal tersebut sesuai dengan kegiatan penelitian yang telah dilakukan, guru dan peneliti merencanakan dan melaksanakan tindakan penelitian dengan menerapkan media bulletin board dengan menyelipkan kegiatan bernyanyi. Media bulletin board di desain semenarik mungkin bagi anak, mulai dari kartu gambar, kartu kata dan hiasan pada bulletin board. Dengan begitu anak tertarik untuk memainkan bulletin board dalam kegiatan pembelaran disekolah.

\section{SIMPULAN}

Peningatan kemampuan membaca permulaan TK PAUD Anak Bangsa Kota Palembang Provinsi Sumatera Selatan melalui media bulletin board menunjukkan hasil analisis rata-rata tingkat capaian perkembangan kemampuan membaca permulaan anak pada siklus I yaitu sebesar 52 yang berada pada kategori berkembang sesuai harapan. Dalam pelaksanaan siklus I terlihat peningkatan skor rata-rata tingkat capaian perkembangan kemampuan membaca anak secara menyeluruh sebesar 8, dengan nilai tingkat capaian perkembangan rata-rata praintervensi sebesar 44. Pada siklus II nilai rata-rata tingkat capaian perkembangan anak pada kemampuan membaca secara keseluruhan yaitu sebesar 65,125 yang berada pada kategori berkembang sangat baik. Adapun besarnya peningkatan pada siklus II sebesar 10,125. Maka pada akhir siklus II, penelitian dikatakan berhasil karena telah mencapai kriteria keberhasilan yang telah disepakati antara peneliti dan kolaborator.

Media bulletin board dapat digunakan dalam peningkatan kemampuan membaca permulaan anak. Anak yang biasanya belajar membaca menggunakan buku seri, akan lebih tertarik untuk membaca menggunakan media bulletin board. Penerapan media bulletin board dapat 
disesuaikan dengan kebutuhan pembelajaran. Dapat memanfaatkan benda sekitar anak sebagai bahan belajar. Serta dapat menggunakan berbagaimetode belajar yang menyenangkan bagi anak, seperti bercerita menggunakan media bulletin board, bernyanyi dalam mengkreasikan bulletin board, dan bekerjasama dalam melaksanakan kegiatan bermain media bulletin board.

\section{DAFTAR PUSTAKA}

Cooper, Brittant Rhoades, et al. Patterns of Early Reading and Social Skills Associated With Academic Success in Elementary School,. Early Education and Development: Routledge. ISSN: 1556-6935 online. 2014.

Gravois, Michael. 20 Totally Awesome \& Totally Easy Language Arts Bulletin Board. USA: Scholastic Teaching Resources.2003.

Jessica A.R Logan, et al. reading development in young children: genetic and environmental influence. Child Development: November/Desember 2013, Volume 84, Number 6

Owens, Robert E. JR. Language Development An Introduction. New Jersey: Pearson, 2012.

NAEYC. Learning to Read and Write: Developmentally Appropriate Practices for Young Children. May 1998.

Nevo, Eniat dan Bar Kochva, The Relations Between Early Working Abilities And Later Developing Reading Skills: A Longitudinal Study From Kindergarden To Fifth Grade, (international Mind, Brain, and Education), volume 9, number 3.

Papalia, Diane E. dan Ruth Duskin Feldman, Menyelami Perkembangan Manisia.Jakarta: Salemba Humanika. 2014.

Sarah MC Geown. "Synthetic Phonics Vs. An Eclectic Approach To Reading Instruction: Implications For The Skills Predicting Early Reading Acquisition And Development". The Psicology Of Education Review, Volume 39, Number 2, Autumn 2015.

Seefeldt, Carol dan Barbara A. Wasik. Pendidikan Anak Usia Dini, Menyiapkan Anak Usia Tiga, Empat, Dan Lima Tahun Masuk Sekolah. Jakarta: Indeks. 2008.

Soekanto, Soejono. Sosiologi Suatu Pengantar,Jakarta: Rajawali Pers, 2012.

Stein, Donna L. Bulletin Board Basics. the Journal of continuing education in nursing. vol 40, no 10.October, 2009.

Sue Hamilton Smith \& Dan Georgeson. Language to Literacy: Profesional Development for the Early Learning Sector 0-5 years. Volume 20, Number 1, Februari 2015.

ULU Hacer \& Hayati AKYOL. The Effect Of Repetitive Reading And PQRS Strategy In The Development Of Reading Skill. Eurasian Journal Of Education Research, Isuue 63, 2016.

Wildova, Radka \& Jana Kropackova.Early Childhood Pre-reading Literacy Development.Elsevier: Journal Procedia- Social and Behacioral Science, 2015. 